\author{
KS. GRZEGORZ LESZCZYŃSKI \\ Wydział Prawa i Administracji \\ Uniwersytetu Łódzkiego \\ ORCID: 0000-0003-4189-5165
}

\title{
SKARGA POWODOWA W PROCESIE BISKUPIM
}

Treść: Wstęp. - 1. Favor veritatis i favor matrimonii. - 2. Pozew - początek procesu. -3 . Pewność rozpadu małżeństwa. -4 . Trybunał kompetentny. - 5. Zawartość pozwu.

\section{Wstęp}

Proces biskupi, czyli inaczej mówiąc skrócony, stanowi nowe wyzwanie dla trybunałów kościelnych. Nie wnikając w szczegóły postępowania, należy jedynie zauważyć, że proces ten może być przeprowadzony po spełnieniu dwóch podstawowych warunków: żądanie zostało zgłoszone przez obydwoje małżonków lub przez jednego z nich za zgodą drugiego; przytaczane są okoliczności dotyczące faktów lub osób, poparte zeznaniami lub dokumentami, które nie wymagają przeprowadzenia dokładniejszego badania albo dochodzenia oraz w sposób oczywisty wskazują na nieważność (kan. 1683 MIDI)1. Możliwość zastosowania procesu skróconego wydaje się zatem oczywista jedynie w sytuacjach oczywistych. Praktyka jednak wskazuje, że w niewielu tak naprawdę sprawach oczywistość faktów, zwłaszcza na początkowym etapie postępowania, jest jednoznaczna. Nie wykluczając jednak takiej możliwości należy zauważyć, że istnieje jeszcze

\footnotetext{
${ }^{1}$ Por. Papież Franciszek, List apostolski Mitis Iudex Dominus Iesus reformujący kanony Kodeksu Prawa Kanonicznego dotyczące spraw o orzeczenie nieważności małżeństwa (tekst łacińsko-polski), Tarnów 2015, s. 9.
} 
drugi warunek istotny, a mianowicie zgodność obojga małżonków, co w procesach kościelnych występuje w mniejszości przypadków. Zakładając jednak, że zostaną spełnione obydwa warunki i zostanie podjęta przez wikariusza sądowego decyzja o przeprowadzeniu procesu skróconego to ryzyko przeprowadzenia takiego procesu w odniesieniu do niewystarczalności zebranych dowodów w czasie jednej sesji sądowej jest niewielkie. W sytuacji bowiem, gdy zebrany materiał dowodowy nie przekona biskupa diecezji do wydania wyroku pro nullitate sprawa powraca do postępowania zwyczajnego. Troska Papieża Franciszka w przedstawionych założeniach dotyka jednak nie kwestii czysto proceduralnych, ale ze względu na szybkość procesu skróconego odnosi się do gwarancji poszanowania zasady nierozerwalności małżeństwa. Sam Papież bowiem stwierdza: „Nie umknęło jednak mojej uwadze, jak bardzo postępowanie skrócone może zagrozić zasadzie nierozerwalności małżeństwa”2. Ta świadomość skłania Papieża do określenia wyłącznej kompetencji biskupa diecezji do orzekania w procesie skróconym, gdyż tylko „biskup ${ }^{3}$, który mocą swego zadania pasterskiego daje największą gwarancję katolickiej jedności z Piotrem w wierze i dyscyplinie" 4 .

\section{Favor veritatis i favor matrimonii}

Sprawiedliwy sąd opiera się na dążeniu do prawdy. Jak zauważa Ojciec Święty Jan Paweł II w przemówieniu do Roty Rzymskiej wygłoszonym w roku 2005, kryterium inspirującym posługę każdego sędziego w procesie kanonicznym jest jego umiłowanie prawdy. Aby mógł on spełnić swoją posługę w sposób rzetelny winien przede wszystkim wierzyć, że prawda istnieje i próbować ją określić, wbrew wszelkim trudnościom i nieporozumieniom. Więcej, jak mówi

2 Tamże, s. 13.

${ }^{3}$ W założeniach do reformy procesu użyty jest termin „biskup”, choć należy przez to rozumieć biskupa diecezjalnego, gdyż taki termin istnieje w przepisach poszczególnych kanonów odnoszących się do procesu skróconego (np. kan. 1687 $\$ 1$ MIDI).

${ }^{4}$ Papież Franciszer, List apostolski Mitis Iudex Dominus Iesus, dz., cyt. s. 13. 
Papież, sędzia kościelny nie może bać się prawdy, ulegając bojaźni niezaspokojenia kogoś oczekiwań lub aspiracji. Prawda, którą jest Chrystus, co podkreśla Papież, wyzwala nas od jakiejkolwiek formy kompromisu $\mathrm{z}$ interesowną nieprawdą ${ }^{5}$.

W obecnym świecie pojawiają się czasem głosy sugerujące konieczność zastąpienia prawdziwego procesu sądowego jakąś jego skróconą formą lub wręcz jego mistyfikacją. Racją takiej decyzji miałaby być konieczność czy potrzeba duszpasterska, oparta na coraz większej ilości małżeństw rozwiedzionych, a także osób pozostających w związkach niesakramentalnych. Jak stwierdza Ojciec Święty Jan Paweł II w przywołanym przed chwilą przemówieniu z roku 2005, w procesie kanonicznym najważniejsza jest prawda obiektywna. Winni o tym pamiętać zarówno biskupi diecezjalni, jak i trybunały, które w ich imieniu wykonują władzę sądowniczą w diecezji ${ }^{6}$. W sprawach małżeńskich każda sentencja sprawiedliwa, a więc oparta na prawdzie o danym małżeństwie, niezależnie od tego, czy orzeka się w niej nieważność czy też ważność małżeństwa, tak naprawdę wnosi swój wkład w umacnianie najważniejszej zasady nierozerwalności małżeństwa. I przeciwnie, każda sentencja niesprawiedliwa, oparta na fałszu, utwierdza w imieniu Kościoła przekonanie o rozerwalności małżeństwa. W ostatnich latach w sposób szczególny, co podkreśla Papież w przemówieniu skierowanym do Roty Rzymskiej w roku 2002, próbuje się zastąpić tradycyjne favor matrimonii podkreśleniem wolności człowieka i wartości osoby. W konsekwencji rozumiejąc przedziwnie wartość osoby i jej wolność relatywizuje się prawdę o małżeństwie i jego nierozerwalność. Nie wolno jednak przeciwstawiać małżeństwu wolności, gdyż każdy z małżonków wybierając małżeństwo w sposób wolny zobowiązał się jednocześnie do przestrzegania obiektywnych wymogów rzeczywistości małżeńskiej. Stąd favor veritatis wymaga

\footnotetext{
${ }^{5}$ Por. Joannes Paulus II, Ad Romanae Rota auditores, oficiales et advocatos coram admissos (29 Ianuarii 2005), AAS 97, 2005, n. 5, s. 166.

${ }^{6}$ Por. tamże, n. 4, s. 165.
} 
od każdego sędziego uznania favor indissolubilitatis matrimonii ${ }^{7}$. Więcej prawdziwe favor matrimonii identyfikuje się z favor veritatis. Jak podkreśla Papież: Każda sentencja sprawiedliwa orzekajaca ważność lub nieważność małżeństwa umacnia kulturę nierozerwalności zarówno w Kościele jak i wświecie ${ }^{8}$.

\section{Pozew - początek procesu}

Wydawałoby się, że z logicznego punktu widzenia coś, co jest skrócone, z pewnością jest bardziej korzystne. Tak może się wydawać, biorąc pod uwagę ekonomię czasową trwania procesu. Czy jednak proces skrócony rzeczywiście jest bardziej korzystny dla stron procesowych czy raczej utrudnia rzetelne przeprowadzenie sprawy? Warto spojrzeć na zalety i wady procesu skróconego by następnie zastanowić się w czym przeważa proces zwykły, o ile przeważna, albo w czym ustępuje procesowi skróconemu, który w końcu został obwieszczony jako jedno z najważniejszych czy wręcz najważniejsze novum reformy procesowej Papieża Franciszka.

Każdy proces o stwierdzenie nieważności małżeństwa, niezależnie od przyjętej formy, rozpoczyna się przedstawieniem pozwu ${ }^{9}$. Sędzia, zgodnie z art. 114 Instrukcji Dignitas connubbi nie może rozpoznać żadnej sprawy, dopóki nie zostanie przedstawiona prośba przez tego, kto ma prawo zaskarżyć małżeństwo ${ }^{10}$. Niezmiennie prawo zaskarżania małżeństwa mają małżonkowie oraz rzecznik sprawiedliwości, kiedy nieważność małżeństwa została już rozgłoszona, jeżeli małżeństwo nie może zostać uważnione albo nie jest to wskazane (kan. 1674 $\$ 1$ MIDI). Oznacza to, że niezmieniona została zasada, że jedynymi osobami uprawnionymi do zaskarżania małżeństwa są małżonkowie

${ }^{7}$ Por. Joannes Paulus II, Ad Romanae Rotae tribunal (28 Ianuarii 2002), AAS 94, 2002, n. 7, s. 345.

8 Tamże.

${ }^{9}$ Por. J. Hervada, Reflexiones acerca de la prudencia jurídica y el Derecho Canónico, w: El Ordo universalis como fundamento de una conceptión cristiana del derecho y otros escritosde la primera época, Pamplona 2014, s. 215-257.

${ }^{10}$ Por. kan. 1501 KPK; Pontificio Consilio Per I Testi Legislativi, Istruzione Dignitas connubbi, Città del Vaticano 2005, art. 92-93. 
i rzecznik sprawiedliwości ${ }^{11}$. Co więcej, zgodnie z papieskim dokumentem małżeństwo, które za życia obojga małżonków nie zostało zaskarżone, po śmierci jednego lub obojga małżonków nie może być zaskarżone, chyba że kwestia ważności ma charakter przed procesowy dla rozwiązania innego sporu bądź na forum kanonicznym bądź na forum świeckim (kan. $1674 \$ 2$ MIDI).

\section{Pewność rozpadu małżeństwa}

Niezwykle ważną normę dla przedłożenia pozwu i jego ewentualnego przyjęcia zawiera przepis zawarty w kan. 1675 MIDI, w myśl którego sędzia, przed przyjęciem sprawy, winien mieć pewność, że małżeństwo się rozpadło w sposób nieodwracalny, tak iż nie ma możliwości wznowienia wspólnoty życia małżeńskiego. W toczących się czasami dyskusjach na temat konieczności wymagania dokumentu rozwodowego w momencie składania pozwu, norma ta, która wskazuje, że proces może mieć miejsce, jakkolwiek niejednoznacznie, rzuca nowe światło na toczące się dyskusje. Co, bowiem, oznacza pewność, że małżeństwo rozpadło się w sposób nieodwracalny. Jak zauważa M. Wolczko jest to norma praktyczna i oznacza, że proces może mieć miejsce wówczas, kiedy nie ma już możliwości na ewentualne uważnienie małżeństwa i wznowienie wspólnoty życia małżeńskiego, w czym wyrok rozwodowy może stanowić argument znaczący i potwierdzający całkowity rozpad życia małżeńskiego ${ }^{12}$. Jakkolwiek zatem wyrok rozwodowy nie stanowi warunku złożenia pozwu, niemniej w świetle normy, o której mowa ma znaczenie istotne. W przeciwnym wypadku zawsze mogą zaistnieć wątpliwości co do całkowitego rozpadu życia małżeńskiego, zwłaszcza że w świetle kan. 1446 KPK z 1983 r. sędzia, na początku sprawy, a także w każdym innym czasie, dostrzegając jakąkolwiek nadzieję dobrego wyniku, powinien zachęcić strony i dopomóc im, by szukały słusznego roz-

\footnotetext{
${ }^{11}$ Por. M. Wolczko, Prawo zaskarżania małżeństwa, w: Praktyczny komentarz do Listu apostolskiego motu proprio Mitis Iudex Dominus Iesus papieża Franciszka, Tarnów 2015, s. 86.

12 Tamże, s. 89-90.
} 
wiązania sporu przez wspólne porozumienie, i wskazać odpowiednie do tego drogi. W tym miejscu warto zauważyć, że nie przypadkiem wprowadzona została norma zawarta w art. 2-5 Zasad proceduralnych zawartych w Mitis Iudex Dominus Iesus sugerująca przeprowadzenie badania przedprocesowego na poziomie diecezjalnym bądź parafialnym. Badanie to, zwane również duszpasterskim, ma na celu przede wszystkim rozpoznanie sytuacji wiernych żyjących w separacji lub rozwiedzionych oraz zebranie informacji, które mogą być użyteczne dla ewentualnego procesu o stwierdzenie nieważności małżeństwa. Oczywiście badanie to, przeprowadzone przez kompetentne osoby, w tym mające wiedzą kanoniczną, nie zastępuje procesu, a jest jedynie przygotowaniem do prowadzenia procesu, zwłaszcza, że niejasny jest przepis dotyczący kompetencji osób przeprowadzających takowe badanie ${ }^{13}$.

\section{Trybunał kompetentny}

Pozew, czyli petitio, ma swojego adresata. Nie może być skierowany gdziekolwiek i do jakiegokolwiek trybunału, a w przypadku procesu skróconego do jakiegokolwiek biskupa. Reforma procesu małżeńskiego dokonana przez papieża Franciszka zmieniła kompetencje trybunałów zastępując dotychczasowe cztery (miejsce zawarcia małżeństwa, miejsce zamieszkania strony pozwanej, miejsce zamieszkania strony powodowej, miejsce zbierania dowodów) trzema, przy wyraźnie zauważanym większym zaufaniu do stron prowadzących postępowanie kanoniczne. W świetle, bowiem, kan. 1672 MIDI w sprawach o nieważność małżeństwa, które nie są zarezerwowane Stolicy Apostolskiej, właściwe są: trybunał miejsca, w którym małżeństwo zostało zawarte; trybunał miejsca, w którym jedna ze stron lub obie strony mają stałe lub tymczasowe miejsce zamieszkania; trybunał miejsca, w którym faktycznie trzeba będzie zebrać większość dowodów. Zauważalna, zatem, jest zmiana, gdyż nie ma już mowy

\footnotetext{
${ }^{13}$ Por. U. Nowicka, B. Nowakowski, Od skargi powodowej do decyzji Roty Rzymskiej. Proces o nieważność małżeństwa po Mitis Iudex w pytaniach i odpowiedziach, Warszawa 2017, s. 27-28.
} 
o zgodzie wikariusza sądowego jak to było w przypadku starych przepisów. Jak słusznie zauważa A. Sosnowski, aktualnie prawodawca wyraża większe zaufanie do stron procesowych, które powinny być świadome powagi prowadzonego procesu. Możliwość prowadzenia procesu w trybunale stałego lub tymczasowego miejsca zamieszkania strony powodowej jest wyjściem naprzeciw potrzebom pastoralnym i zakłada, że strona ta nie będzie rozpoczynała procesu w taki sposób by uniemożliwić stronie pozwanej czynnego udziału we wszystkich etapach postępowania ${ }^{14}$. Ponadto, co należy podkreślić, nie ma pierwszeństwa kompetencji, gdyż każdy ze wskazanych trybunałów jest równie kompetentny i to od strony powodowej zależy do którego trybunału złoży pozew. Pewne wątpliwości pojawiają się jednak, jeśli idzie o pozew w trybie procesu skróconego. Jak słusznie zauważa Del Pozzo, skoro proces skrócony winien dokonać się w trakcie jednej sesji sądowej, cokolwiek to znaczy, a czas trwania owej sesji może być różny, to wydaje się, że najbardziej wskazanym trybunałem byłby ten, w którym rzeczywiście można zebrać jak najwięcej przekonujących i silnych dowodów. I nie dotyczy to ilości dowodów, ile raczej ich ciężaru i jakości ${ }^{15}$.

\section{Zawartość pozwu}

Pozew, w zależności od typu prowadzonego procesu, może być nieco odmienny, niemniej istnieją pewne elementy, które są wspólne. Każdy pozew winien jasno wskazywać adresata pozwu, czyli trybunał bądź biskupa diecezji, w której ma być prowadzony proces. Winien też wskazywać przynajmniej w sensie ogólnym przedmiot prośby, czyli tytuły nieważności małżeństwa, z których ma być prowadzona sprawa. Z oczywistych względów pozew winien zawierać fakty świadczące zdaniem wnioskującego o nieważności małżeństwa oraz przynajmniej ogólnie dowody potwierdzające tezę nieważność.

\footnotetext{
${ }^{14}$ Por. A. Sosnowski, Właściwość sądu i trybunały, w: Praktyczny komentarz..., dz. cyt., s. 62.

${ }^{15}$ Por. M. DEL Pozzo, Il processo matrimoniale più breve davanti al Vescovo, Roma 2016, s. 130-131.
} 
W sensie formalnym winien zawierać dane stron, zwłaszcza jeśli idzie o aktualne adresy zamieszkania, chyba że ewidentnie jest to trudne do ustalenia. Wreszcie w końcu pozew winien zawierać podpis strony powodowej bądź stron procesowych, miejsce i datę napisania pozwu. Oprócz wymagań wspólnych, które dotyczą wszystkich typów procesów istnieją pewne charakterystyczne, które dotyczą procesu skróconego ${ }^{16}$.

Pozew w procesie skróconym winien zostać zgłoszony przez obydwoje małżonków lub przez jednego z nich za zgodą drugiego. Winien też zawierać okoliczności dotyczące faktów lub osób, poparte zeznaniami lub dokumentami, które nie wymagają przeprowadzenia dokładniejszego badania albo dochodzenia oraz w sposób oczywisty wskazują na nieważność (kan. 1683 MIDI). Oznacza to, ze strony procesowe w przypadku pozwu do procesu skróconego stają po tej samej stronie powództwa skarżąc małżeństwo i jego ważność. Wydaje się zatem zasadne, że w tym przypadku to obrońca węzła małżeńskiego staje się stroną przeciwną w sporze. Słusznie jednak zauważa P. Majer, że stawianie takiego warunku może sugerować nierzetelność postępowania $\mathrm{z}$ racji na przeświadczenie stron, iż podpisanie się pod wspólnym żądaniem ułatwi i przyśpieszy znacząco procedurę. Równie duże obawy można mieć w stosunku do drugiego warunku zastosowania procesu skróconego, a zwłaszcza do rozumienia sformułowania „w sposób oczywisty” wskazując na nieważność małżeństwa ${ }^{17}$.

W swoim przemówieniu wygłoszonym 25 listopada 2017 r. do uczestników kursu zorganizowanego przez Trybunał Roty rzymskiej Papież Franciszek w punkcie 5 stwierdza wyraźnie: l'istanza va sempre indirizzata al Vescovo diocesano. Oznacza to, że strony proszące o przeprowadzenie procesu skróconego winny swoją prośbę kierować bezpośrednio do biskupa diecezjalnego. Wydaje się jednak, że niezależnie od tego czy pozew zostanie skierowany do biskupa

\footnotetext{
${ }^{16}$ Por. La riforma dei processi matrimoniali di Papa Francesco. Una guida per tutti, red. Redazione di Quaderni di Diritto Ecclesiale, Milano 2016, s. 32

${ }^{17}$ Por. P. MAJER, Procres małżeński skrócony przed biskupem, w: Praktyczny komentarz, dz. cyt., s. 167-168.
} 
diecezji czy do kompetentnego trybunału, to wikariusz sądowy, zgodnie z kan. $1676 \$ 2$ MIDI, decyduje o wyborze typu procesu. Co należy podkreślić, proces skrócony nie jest postępowaniem administracyjnym, jak mogła by sugerować pierwszorzędna rola biskupa diecezjalnego, ale jest postępowaniem sądowym prowadzonym wobec biskupa diecezjalnego i zrównanych z nim przełożonych Kościołów partykularnych (kan. $135 \$ 3 \mathrm{KPK}$ ). Co więcej biskup diecezjalny nie może władzy sądowniczej delegować nikomu innemu, jak np. wikariuszowi sądowemu, co z pewnością byłoby użyteczne w wielu przypadkach z merytorycznego punktu widzenia. Nie może tego właśnie dlatego, że to biskup diecezjalny ma być gwarantem sprawiedliwego działania w przypadku procesu skróconego ${ }^{18}$.

Prawodawca w kan. 1684 MIDI wskazuje w sposób konkretny trzy elementy charakterystyczne pozwu składanego w celu przeprowadzenia procesu skróconego. Pozew ten winien przedstawić krótko i całościowo fakty, na których opiera się żądanie; wskazać dowody, które mogłyby być natychmiast zebrane przez sędziego; zawierać w załączeniu dokumenty, na których opiera się żądanie. Z przytoczonych wskazań wynika jasno, że pozew w procesie skróconym nie może ograniczyć się jedynie do wskazania w sensie bardzo ogólnym faktów potwierdzających nieważność małżeństwa, ale winien wskazywać też na dowody, które mogą być czym prędzej zebrane. Wynika $z$ tego, że wykluczone są dowody, które ze względu na odległość zamieszkania od sądu świadków bądź czas zbierania dowodów nie mogą być użyte w procesie skróconym. Podobnie rzecz dotyczy dokumentów, które w procesie skróconym winny być załączone już w momencie składania pozwu.

\section{Tytuły nieważności a okoliczności}

Jest oczywiste, że pozew winien zawierać określone żądanie, czyli wskazywać na tytuł nieważności małżeństwa. Fakty, o których mowa wyżej, mają przecież uzasadniać oczywistość żądania w przypadku pozwu do procesu skróconego. W przypadku procesu zwykłego fakty

\footnotetext{
${ }^{18}$ Por. tamże, s. 164-165.
} 
jakkolwiek nie muszą w sposób oczywisty świadczyć o nieważności małżeństwa, niemniej tę nieważność w sposób ogólny winny potwierdzać.

Najczęściej spotykane w postępowaniu sądowym tytuły nieważności małżeństwa dotyczą z jednej strony różnych form niezdolności konsensualnej, o których mowa w kan. 1095, 1-3 KPK, z drugiej zaś różnych form symulacji zgody małżeńskiej, bądź całkowitej bądź częściowej. W przypadku pozwu do procesu skróconego wydaje się być ciekawym zestawienie ich z okolicznościami, o których mowa w art. 14 Zasad proceduralnych określonych przez Papieża Franciszka. Trudno, bowiem, rozpatrywać każdą z tych zasad oddzielnie i dopasowywać do nich poszczególne tytuły nieważności. W moim przekonaniu, tok rozumowania winien być przeciwny, tzn. możliwość zastosowania konkretnego tytułu nieważności małżeństwa winno być uzasadnione istnieniem niektórych okoliczności, które zresztą nie taksatywnie, wymienia Prawodawca we wspomnianym art. 14 Zasad proceduralnych.

To oczywiste, że brak wystarczającego używania rozumu, jakkolwiek w myśl kan. 97 i kan. 124 KPK czyni osobę niezdolną do wyrażenia jakiegokolwiek aktu ludzkiego, w świetle kan. 1095, 1 KPK oznacza brak takiego stopnia używania rozumu, który konieczny jest do zaistnienia aktu ludzkiego, jakim jest akt zgody małżeńskiej $^{19}$. Brak wystarczającego używania rozumu w odniesieniu do aktu zgody małżeńskiej nie oznacza zatem, że dany podmiot nie jest zdolny do wyrażenia innego aktu prawnego o mniejszym znaczeniu. Pozbawiony wystarczającego używania rozumu jest ten podmiot, który w momencie wyrażenia konsensu z jakiejkolwiek przyczyny nie posiada pełnego i harmonicznego zarządzania swoimi władzami zmysłowymi, pożądawczymi, umysłowymi i wolitywnymi, które jest konieczne do tego, aby akt zawarcia małżeństwa był aktem ludzkim. Przyczyny braku wystarczającego używania rozumu mogą mieć charakter habitualny lub aktualny. Jak zauważa P. Moneta, do najczęściej

\footnotetext{
${ }^{19}$ Por. A. Aвате, Il consenso matrimoniale nel nuovo Codice di Diritto Canonico, Appolinaris 59, 1986, s. 455.
} 
spotykanych przyczyn o charakterze habitualnym zalicza się choroby umysłowe oraz psychozy, takie jak schizofrenia, paranoja, psychoza maniakalno-depresyjna ${ }^{20}$. Zestawiając to co wyżej napisano z zasadami proceduralnymi można stwierdzić, że jeśli w momencie składania pozwu można stwierdzić, że istnieją dokumenty medyczne potwierdzające brak używania rozumu, brak świadomości działania z powodu konkretnego zaburzenia umysłowego bądź psychicznego istnieje podstawa do złożenia pozwu wnoszącego o przeprowadzenie procesu skróconego.

Podobnie ma się rzecz w odniesieniu do tytułu poważnego braku rozeznania oceniającego. Poważny brak rozeznania oceniającego co do praw i obowiązków małżeńskich oznacza brak zdolności osądu proporcjonalnego do istoty małżeństwa oraz brak wolności wewnętrznej koniecznej do wyrażenia zgody małżeńskiej. Ma on miejsce w przypadku poważnego naruszenia zdolności poznawczych, krytycznych i wolitywnych w stosunku do przekazania i przyjęcia praw i obowiązków małżeńskich. Przyczyny poważnego braku rozeznania oceniającego mogą mieć różny charakter. Zalicza się do nich najczęściej psychozy, nerwice czy zaburzenia, czy też patologie osobowości ${ }^{21}$. To, co powiedziano odnośnie do pierwszego tytułu nieważności można zastosować i w tym przypadku, jeśli idzie o dokumenty medyczne potwierdzające istnienie silnego zaburzenia psychicznego w momencie zawierania małżeństwa. Dodatkowo nie bez znaczenia mogą być inne okoliczności, jak np. krótkie pożycie małżeńskie czy stosowana przemoc fizyczna. Wydaje się, że o wiele trudniej będzie można znaleźć okoliczności, które uzasadniają wniesienie pozwu z tytułu niezdolności natury psychicznej do podjęcia istotnych obowiązków małżeńskich, chyba że mowa o zaawansowanych uzależnieniach,

\footnotetext{
${ }^{20}$ Por. P. Moneta, Il Matrimonio, w: Il Diritto nel Mistero della Chiesa, t. 3, Roma 1992, s. 221; J. J. GARCía FAÍlde, Trastornos psíquicos y nulidad del matrimonio, Salamanca 1999, s. 336.

${ }^{21}$ Por. ST. PAźDzIor, Przyczyny poważnego braku rozeznania oceniajacego $w$ świetle kan. 1095 n. 2, Lublin 2004, s. 25-26.
} 
jak np. uzależnienie od alkoholu potwierdzone dokumentami medycznymi np. w postaci podjętego leczenia.

Warto zauważyć, że zatajenie alkoholizmu czy jakiegokolwiek innego uzależnienia bądź zaburzenia, a także bezpłodności, o ile jest to udokumentowane, może stanowić podstawę wniesienia pozwu $\mathrm{z}$ tytułu podstępnego wprowadzenia w błąd.

$\mathrm{W}$ prawie małżeńskim materialnym symulacja oznacza sfałszowaną zgodę małżeńską, w której wyrażona za pomocą słów i znaków zewnętrzna deklaracja woli nie odpowiada zgodzie wewnętrznej ${ }^{22}$. W przypadku symulacji istnieje rozbieżność między rzeczywistą wolą kontrahenta i jej zewnętrzną formą wyrazu. Oznacza to, iż strony, pomimo że pragną nadać wyrażanej przez nich zgodzie małżeńskiej zewnętrzną formę i czynią to $\mathrm{w}$ rzeczywistości, wewnętrznie nie zgadzają się z jej przedmiotem, niezależnie od tego, czy będzie nim małżeństwo jako takie, czy któryś z jego przymiotów lub elementów ${ }^{23}$. Co więcej, strony wyrażające wolę małżeńską nie tylko nie zgadzają się z przedmiotem zgody małżeńskiej, ale wykluczają go pozytywnym aktem woli, jak stwierdza kan. $1101 \S 2$ KPK z 1983 r. Powyższa norma kan. $1101 \$ 2$ obecnie obowiązującego Kodeksu Prawa Kanonicznego rozróżnia przedmiot symulacji, przez dokonanie rozróżnienia między wykluczeniem samego małżeństwa, jak i jego istotnych elementów i przymiotów oraz wskazuje na pozytywny akt woli jako niezbędny do uznania działania osoby zawierającej małżeństwo symulowane. W przypadku symulacji całkowitej kontrahent nie ma w ogóle woli zawarcia związku, w przypadku symulacji częściowej istnieje wola zawarcia związku, natomiast wykluczony zostaje element lub przymiot małżeństwa.

Istnieją okoliczności, które w świetle art. 14 Zasad proceduralnych mogą uzasadniać złożenie pozwu z tytułu symulacji zgody małżeńskiej. I tak, dla przykładu, brak wiary może uzasadniać wykluczenie

\footnotetext{
22 Por. R. BACARI, La volontà nei sacramenti, Milano 1941, s. 173; G. DzIERżon, Niezdolność do zawarcia małżeństwa jako kategoria kanoniczna, Warszawa 2002, s. 240 .

${ }^{23}$ Por. F. Ferrara, Della simulazione dei negozi giuridici, Milano 1913, s. 37.
} 
małżeństwa, wykluczenie godności sakramentalnej małżeństwa a nawet błąd determinujący wolę. Aborcja dokonana dla uniknięcia posiadania potomstwa może uzasadniać tytuł wykluczenia dobra potomstwa. Pozostawanie w relacji pozamałżeńskiej w okresie zawierania małżeństwa może stanowić podstawę wniesienia pozwu z tytułu wykluczenia jedności małżeńskiej albo przynajmniej z tytułu wykluczenia dobra wierności i małżeńskiej. Zawarcie małżeństwa z przyczyny całkowicie obcej życiu małżeńskiemu może uzasadniać tytuł wykluczenia małżeństwa bądź tytuł wykluczenia dobra małżonków. Jak zatem łatwo zauważyć okoliczności, o których mowa w art. 14 Zasad proceduralnych, jakkolwiek nie wyczerpują możliwej listy okoliczności uzasadniających wniesienie pozwu ze wskazaniem procesu skróconego, niemniej mogą uzasadniać taką decyzję powództwa ${ }^{24}$.

$$
* * *
$$

Złożenie pozwu to początek procesu skróconego. To od wikariusza sądowego zależy, czy spełnia on określone kryteria i czy może stanowić podstawę prowadzenia procesu, który stanowi absolutne novum w procedurze kanonicznej.

\section{Introductory petition in the short process}

Every marriage process going to declare the nullity, regardless of its form, starts from introductory petition. A judge cannot examine any case until the petition is put forward by the one who can challenge the validity of marriage. Spouses and a promotor of justice have an unchangeable right to challenge the validity of marriage in some circumstances. This article is an attempt to define and determine the circumstances in which the parties can file for a shortened process, or the so called bishop process.

\footnotetext{
${ }^{24}$ Por. L. Adamowicz, Okoliczności zezwalające na prowadzenie procesu skróconego, w: Proces małżeński według motu proprio Mitis Iudex Dominus Iesus, red. J. Krajczyński, Płock 2015, s. 101.
} 
SŁowA KLUCzOWE: Papież; proces; nieważność małżeństwa; reforma

KEYWORDS: Pope; process; marriage nullity; reform

Nota o Autorze:

Ks. PROF. DR hAB. GRZEgorz LeszCZyŃski - profesor zwyczajny na Wydziale Prawa i Administracji Uniwersytetu Łódzkiego, Oficjał Trybunału Archidiecezji Łódzkiej. 